\title{
Flavobacterium spiritivorum, a New Species Isolated from Human Clinical Specimens
}

\author{
B. HOLMES, ${ }^{1}$ R. J. OWEN, ${ }^{1}$ AND D. G. HOLLIS ${ }^{2}$ \\ National Collection of Type Cultures, Central Public Health Laboratory, London NW9 5HT, United \\ Kingdom, ${ }^{1}$ and Centers for Disease Control, Atlanta, Georgia $30333^{2}$
}

\begin{abstract}
A new species, Flavobacterium spiritivorum, is proposed. Each of the 13 strains placed in the new species was examined for 129 characteristics, including 58 enzyme reactions (API ZYM system). These bacteria were rod shaped, aerobic, gram negative, and nonmotile, and oxidized glucose in oxidationfermentation medium. The mean guanine-plus-cytosine content of the deoxyribonucleic acids of six selected strains was $41.4 \pm 0.4 \mathrm{~mol} \%$. A distinguishing feature of the new species is its ability to produce acid from various carbohydrates and alcohols. In particular, the ability of $F$. spiritivorum strains to produce acid from ethanol and mannitol distinguishes them from all other Flavobacterium species. Eleven strains of the new species were isolated from human clinical specimens, of which blood and urine were common sources. The type strain is E7288 (= NCTC 11386).
\end{abstract}

The name Pseudomonas paucimobilis was proposed (9) for various yellow-pigmented, clinically isolated bacteria which were received at the National Collection of Type Cultures for identification and which were similar to strains of Centers for Disease Control group Ilk biotype 1 (26). The name Flavobacterium multivorum was proposed (10) for strains that belonged to group IIk biotype 2 . The degree of relatedness between biotype 1 and biotype 2 strains was confused in the past because of their apparent overall phenotypic similarity (26). However, guanine-plus-cytosine $(\mathrm{G}+\mathrm{C})$ contents of the deoxyribonucleic acids (DNAs) $(9,10)$ and cellular fatty acid compositions (3) demonstrated that the two biotypes were not closely related and belonged in different genera.

The present study describes the characteristics of 13 strains that resemble those of group IIk biotype 2 yet differ from $F$. multivorum, and we present evidence that they constitute a new species, herein named Flavobacterium spiritivorum. The strains included in the new species were previously referred to as "group IIk, type 3 " (8), because they seemed likely to provide the basis of a new taxon (10).

\section{MATERIALS AND METHODS}

Bacterial strains. The 13 bacterial strains studied and the sources from which they were isolated are given in Table 1.

Bacteriological investigations. The strains were maintained on nutrient agar (Oxoid nutrient broth powder CM 67, $25 \mathrm{~g}$, and New Zealand Agar, $12 \mathrm{~g}$, per liter of distilled water) under aerobic conditions and were tested at their optimal growth temperature, about $30^{\circ} \mathrm{C}$. Colonial morphology was described from aerobic growth on nutrient agar, and hemolysis was deter- mined from aerobic growth on $5 \%$ (vol/vol) horse blood agar. Pigmentation was recorded from growth on nutrient and tyrosine agars, and fluorescence in ultraviolet light was tested for on medium B of King et al. (15). The Gram reaction was determined by Lillie's modification as described by Cowan (2). Motility was tested by the hanging-drop method on overnight cultures grown at room temperature $\left(18\right.$ to $\left.22^{\circ} \mathrm{C}\right)$ and at $37^{\circ} \mathrm{C}$ in nutrient broth (Oxoid CM 67).

The biochemical characteristics investigated are listed in Tables 2, 3, and 4, and the methods used were described by Holmes et al. (6), but with the following changes or additions. Indole production was tested with Kovacs' reagent and with Ehrlich's reagent, the latter by method 3 of Cowan (2). Tributyrin hydrolysis was tested for on nutrient agar containing $1 \%(\mathrm{vol} / \mathrm{vol})$ glycerol tributyrate, as described by Hayes (4). Phosphatase production was determined by method 1 of Cowan (2). Tests for the detection of 58 specific enzymes (listed in Tables 2-4) were performed with a commercially produced kit system (API System, La Balme-les-Grottes, 38390 Montalieu-Vercieu, France). The structure of the ZYM gallery, the choice of substrates, how the enzymes are detected, and the various applications of the system are fully described elsewhere (D. Monget, Ph.D. thesis, Université Claude Bernard, Lyon, France, 1978). Nineteen of the enzyme tests that constitute the standard API ZYM gallery are available commercially. The remaining 39 enzyme tests constitute four experimental API galleries-ZYM II, AP 1, AP 2, and AP 3. The following standardized procedure was adopted to ensure that results of the enzyme tests were comparable between strains. Each strain was grown overnight on a nutrient agar slant (in 150 - by $15-\mathrm{mm}$ test tubes) at $30^{\circ} \mathrm{C}$. The bacteria were washed off the slant and suspended in 6 $\mathrm{ml}$ of distilled water (API System \#2011) in a 125- by $12.5-\mathrm{mm}$ test tube. The absorbance, at $550 \mathrm{~nm}$, of the resulting bacterial suspension was measured in a Pye Unicam model SP 600 spectrophotometer to check that it was in the 1.0 to 2.0 range. Suspensions with an 
TABLE 1. Strains of $F$. spiritivorum sp. nov. studied

\begin{tabular}{ll}
\hline \multicolumn{1}{c}{ Strain } & \multicolumn{1}{c}{ Source } \\
\hline CL404/79 & Blood, UK \\
CL48/80 & Blood, UK \\
E3438 & Blood, USA (Pennsylvania) \\
A14/65 & Wound swab, UK \\
D3221 & $\begin{array}{l}\text { Sink trap in ambulance, USA (Michi- } \\
\text { gan) }\end{array}$ \\
D3250 & Humidifier sponge in ambulance, USA \\
& (Michigan) \\
D7039 & Peritoneal fluid, USA (Maine) \\
D7211 & Urine, USA (Kansas) \\
E8472 & Urine, USA (Hawaii) \\
D7529 & Sputum, USA (Maine) \\
E6209 & Bone marrow, New Zealand \\
E6826 & Vaginal swab, New Zealand \\
E7288 & Intrauterine specimen, USA (Kansas) \\
\hline
\end{tabular}

TABLE 2. Characteristics in which all 13 strains of $F$. spiritivorum were positive

Acid from the following alcohols and carbohydrates

(tested in an ammonium salt medium):

$\begin{array}{ll}\text { Glucose } & \text { Mannitol } \\ \text { Cellobiose } & \text { Raffinose } \\ \text { Glycerol } & \text { Salicin } \\ \text { Ethanol } & \text { Sucrose } \\ \text { Fructose } & \text { Trehalose } \\ \text { Lactose } & \text { Xylose } \\ \text { Maltose } & \end{array}$

Acid from $10 \%$ (wt/vol) glucose

Catalase production

Cytochrome-oxidase production

Deoxyribonuclease production

Esculin hydrolysis

Gelatinase production (plate method)

Growth at $37^{\circ} \mathrm{C}$

Growth at room temperature $\left(18\right.$ to $\left.22^{\circ} \mathrm{C}\right)$

Growth on MacConkey agar

Growth on $\beta$-hydroxybutyrate

Oxidative in Hugh and Leifson oxidation-fermentation test

Phosphatase production

Production of $\beta$-D-cellobiosidase ${ }^{a}$

Tributyrin hydrolysis

Tween 20 hydrolysis

Tween 80 hydrolysis

Urease production

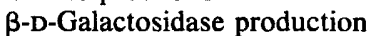

${ }^{a}$ Tested using an API ZYM gallery.

absorbance outside this range were not used because of possible weak color reactions. An absorbance of just over 1.0 was considered by the manufacturer to be most suitable. Two drops of the suspension were inoculated into each cupule of the test galleries, which were incubated at $30^{\circ} \mathrm{C}$ for $4 \mathrm{~h}$. Reagents were then added to each cupule according to the manufacturer's instructions. Positive results in 56 enzyme tests were denoted by a color change. In two additional tests in the ZYM II gallery, positive results were detected by fluorescence under an ultraviolet light source. After reading the results of tests 2 to 10 in the ZYM II gallery, test 1 in that gallery and all the tests in the other four galleries were exposed to a $1,000-\mathrm{W}$ light source. The results were graded 0 to 5 according to the intensity of color change and as based on the interpretation scheme provided by the manufacturer. A positive result in the present paper included all grades of color change in the range 3 to 5 as recommended by the manufacturer.

All 13 strains were tested for susceptibility to antimicrobial agents by methods described previously (19). Two control strains of known susceptibility were included: Escherichia coli ATCC 25922 and Pseudomonas aeruginosa ATCC 27853.

Median organism or centrostrain. The median organism (or centrostrain if there is no median organism) was determined by the method of Lapage and Willcox (16).

DNA isolation. Cultures were grown overnight at $30^{\circ} \mathrm{C}$ in nutrient broth with aeration at $200 \mathrm{rpm}$ in an orbital incubator (Gallenkamp Ltd., London, U.K.). The bacterial cells were collected by centrifuging and were suspended in $0.15 \mathrm{M} \mathrm{NaCl}$ and $0.10 \mathrm{M}$ ethylenediaminetetraacetic acid at $\mathrm{pH}$ 8.0. Pronase (KochLight) was added to a final concentration of $200 \mu \mathrm{g} / \mathrm{ml}$, and the bacteria were lysed with $2 \%$ (wt/vol) sodium lauryl sulfate at $60^{\circ} \mathrm{C}$ for $15 \mathrm{~min}$. The lysate was incubated overnight at $37^{\circ} \mathrm{C}$ and was then mixed thoroughly with $1 \mathrm{M}$ sodium perchlorate and deproteinized with an equal volume of a 50:50 ( $\mathrm{vol} / \mathrm{vol})$ mixture of phenol and chloroform. Purification of the DNA was completed essentially by the method of Marmur (17), but it was supplemented by treatment twice with $50 \mu \mathrm{g}$ of ribonuclease per ml (bovine pancreas, BDH) and final precipitation with 2-ethoxyethanol.

Estimation of $\mathbf{G}+\mathbf{C}$ content of DNA. The $\mathrm{G}+\mathrm{C}$ contents of the DNAs were estimated from the thermal denaturation temperatures $\left(T_{m}\right)$, which were determined by the method of Marmur and Doty (18). Thermal denaturation of DNA was carried out in a Pye Unicam SP 1800 spectrophotometer equipped with an SP 876 series 2 temperature program controller and heated cell block. The absorbance changes at $260 \mathrm{~nm}$ were recorded on a Pye Unicam AR 25 linear recorder. The temperature of the DNA solution was measured in the cuvette with a thermistor thermometer (5). The $\mathrm{G}+\mathrm{C}$ content was calculated from the $T_{m}$ determined in the $0.05 \mathrm{M} \mathrm{NaCl}$ buffered with $0.005 \mathrm{M}$ trisodium citrate $(0.33 \times \mathrm{SSC})$ at $\mathrm{pH} 7.0$ by the equation: mol\% $\mathrm{G}+\mathrm{C}=52.0+\left[2.24\left(T_{m}-84.4\right)\right]$. This was derived by using the general equation of Owen et al. (20), in which the $\mathrm{G}+\mathrm{C}$ content was expressed relative to reference DNA from $E$. coli B NCTC 10537 (52.0 mol\% G+C).

\section{RESULTS}

Phenotypic characteristics of $F$. spiritivorum. The 13 strains were strictly aerobic, gram-negative, uniformly stained rods, $1.0 \mu \mathrm{m}$ in length, with parallel sides and rounded ends. The colonies on nutrient agar, after $48 \mathrm{~h}$, were circular, 1 to $3 \mathrm{~mm}$ in diameter (except D7529, which formed pinpoint colonies), and low convex, smooth, and opaque. A pale yellow pigment was produced by all strains except A14/65 and 
TABLE 3. Characteristics in which all 13 strains of $F$. spiritivorum were negative

Acid from the following alcohols (tested in an ammonium salt medium): Adonitol Inositol

Dulcitol Sorbitol

Alkali production on Christensen's citrate

Arginine desimidase

Arginine dihydrolase

Casein digestion

Fluorescence on King medium B

Gas from glucose in peptone water sugar

Gelatin liquefaction

Gluconate oxidation

Growth at 5 and $42^{\circ} \mathrm{C}$

Growth on cetrimide

Growth on Simmons' citrate

Hydrogen sulfide production ${ }^{a}$

Indole production ${ }^{b}$

Lysine decarboxylase

Malonate utilization

Motility (at both $37^{\circ} \mathrm{C}$ and room temperature)

Nitrate and nitrite reduction

Opalescence on lecithovitellin agar

Ornithine decarboxylase

Phenylalanine deamination

Pigment production on tyrosine agar

Poly $\beta$-hydroxybutyrate inclusion granules

Production of the following enzymes ${ }^{c}$ :

Esterase (C-4) ${ }^{d}$

Lipase $(\mathrm{C}-14)^{d}$

L-Valyl-2-napthylamide hydrolase ${ }^{d}$

L-Cystyl-2-naphthylamide hydrolase ${ }^{d}$

$\mathrm{N}$-Glutaryl-L-phenylalanyl-2-naphthylamide hydrolase $^{d}$

$\alpha-\mathrm{D}-$ Galactosidase ${ }^{d}$

$\beta$-D-Glucuronidase ${ }^{d}$

$\alpha$-D-Mannosidase ${ }^{d}$

$\alpha$-D-Xylosidase

$\beta$-D-Fucosidase

$\beta$-L-Fucosidase

$N$-Acetyl- $\alpha$-D-glucosaminidase

Lactosidase

L-Tyrosyl-2-naphthylamide hydrolase

L-Phenylalanyl-2-naphthylamide hydrolase

L-Hydroxyprolyl-2-naphthylamide hydrolase

$N$-Benzoyl-L-leucyl-2-naphthylamide hydrolase

L-Isoleucyl-2-naphthylamide hydrolase

L-Prolyl-2-naphthylamide hydrolase

Reduction of $0.4 \%$ (wt/vol) selenite

Starch hydrolysis

Tyrosine hydrolysis

3-Ketolactose production

${ }^{a}$ By both lead acetate paper and triple sugar iron agar (TSI) methods.

${ }^{b}$ Tested with Kovács' and Ehrlich's reagent.

$c$ Tested using various API ZYM galleries.

${ }^{d}$ Enzyme test included in the standard API ZYM gallery.

CL404/79, which were nonpigmented; the pigment neither diffused in nutrient agar nor fluoresced on King's medium $B$ when exposed to ultraviolet light. None of the strains produced a dark-brown pigment on tyrosine agar. The strains grew optimally at $30^{\circ} \mathrm{C}$, and all biochemical tests, unless specified otherwise, were carried out at this temperature. The strains grew at room temperature and at $37^{\circ} \mathrm{C}$ but not at 5 or $42^{\circ} \mathrm{C}$. Hemolysis was not present after aerobic growth for 1 day on $5 \%$ (vol/vol) horse blood agar.

The biochemical characteristics of the strains are listed in Tables 2 to 4 . Eighty-five characteristics were common to all strains (either all positive or all negative), and there were 44 characteristics in which one or more of the strains differed. Strain E7288 proved to be the centrostrain, as there was no median organism. Strains D3221 and E3438 were the least typical members of $\boldsymbol{F}$. spiritivorum, and each differed from the other 12 strains in two, but not the same two, biochemical characteristics. In Table 2 it should be noted that all strains of $F$. spiritivorum produced phosphatase (method 1 of Cowan [2]) and $\beta$-D-galactosidase (2) by conventional methods, whereas in the API ZYM method, only one strain produced phosphatase and only one strain produced $\beta$-D-galactosidase (Table 4). These discrepancies between the test methods were attributed to the fact that, in the API ZYM method, only grades of color change in the range 3 to 5 were treated as positive. However, in the phosphatase production (API ZYM) test, 12 of 12 strains scored as negative produced a slight color change (grades 1 and 2), and in the $\beta$-D-galactosidase production (API ZYM) test, 10 of 12 strains scored as negative produced a color change (grades 1 and 2). The susceptibilities of the strains to antimicrobial agents are listed in Table 5. All 13 strains were resistant to therapeutic levels of ampicillin, carbenicillin, cephalothin, amikacin, gentamicin, kanamycin, tobramycin, and tetracycline; four strains were susceptible to chloramphenicol; and all were susceptible to rifampin.

G+C content of $\boldsymbol{F}$. spiritivorum DNA. Table 6 lists the $\mathrm{G}+\mathrm{C}$ contents of the DNAs of six phenotypically representative strains of $F$. spiritivorum. The values were between $\mathbf{4 0 . 8}$ and 41.9 mol\%, with a mean of 41.4 mol\% and a standard deviation of $\pm 0.4 \mathrm{~mol} \%$.

\section{DISCUSSION}

The results presented above indicate that the 13 strains of gram-negative, yellow-pigmented bacteria for which the name Flavobacterium spiritivorum (spi.ri.ti'vo.rum. L. noun spiritus spirit; L. adj. suffix -vorus devouring, eating; M.L. adj. spiritivorus spirit-devouring, intended to refer to the ability of the organism to attack spirits, i.e., alcohol, producing acid in the process) is here proposed constitute a homogeneous taxon. This new species conforms to the defini- 
TABLE 4. Characteristics in which the 13 strains of $F$. spiritivorum differ from one another

\begin{tabular}{|c|c|c|c|}
\hline Strain differences & $\begin{array}{l}\text { No. of } \\
\text { strains } \\
\text { positive }\end{array}$ & $\begin{array}{l}\text { Result } \\
\text { of type } \\
\text { strain } \\
\text { (E7288) }\end{array}$ & $\begin{array}{l}\text { Reference no. of strains that gave the less } \\
\text { common result }\end{array}$ \\
\hline Alkaline phosphatase production ${ }^{a, h}$ & $12 / 13$ & + & E3438 \\
\hline Phosphoamidase production ${ }^{a, b}$ & $12 / 13$ & + & D7529 \\
\hline Acid from glucose in peptone water sugar & $11 / 13$ & + & CL404/79, A14/65 \\
\hline Acid from $10 \%(\mathrm{wt} / \mathrm{vol})$ lactose & $11 / 13$ & + & $\mathrm{A} 14 / 65, \mathrm{D} 7211$ \\
\hline Production of yellow pigment & $11 / 13$ & + & CL404/79, A14/65 \\
\hline Acid phosphatase production ${ }^{a, b}$ & $11 / 13$ & + & D7039, D7529 \\
\hline $\begin{array}{l}\text { L-Histidyl-2-naphthylamide hydrolase pro- } \\
\text { duction }^{a}\end{array}$ & $11 / 13$ & + & D7039, E6209 \\
\hline $\begin{array}{l}\alpha \text {-L-Aspartyl-2-naphthylamide hydrolase } \\
\text { production }^{a}\end{array}$ & $11 / 13$ & + & D7039, E6209 \\
\hline$\alpha-\mathrm{D}-$ Glucosidase production ${ }^{a, b}$ & $10 / 13$ & + & D7529, E3438, E8472 \\
\hline $\begin{array}{l}N \text {-Acetyl- } \beta-\mathrm{D} \text {-glucosaminidase produc- } \\
\text { tion }^{a, b}\end{array}$ & $10 / 13$ & + & D7211, D7529, E6826 \\
\hline $\begin{array}{l}\text { L-Alanyl-2-naphthylamide hydrolase pro- } \\
\text { duction }^{a}\end{array}$ & $10 / 13$ & + & D7529, E6209, E6826 \\
\hline $\begin{array}{l}N \text {-Benzoyl-DL-arginyl-2-naphthylamide } \\
\text { hydrolase production }{ }^{a, b}\end{array}$ & $9 / 13$ & + & D3250, D7529, E3438, E6209 \\
\hline $\begin{array}{l}\text { L-Lysyl-2-naphthylamide hydrolase pro- } \\
\text { duction }^{a}\end{array}$ & $9 / 13$ & + & D7529, E3438, E6209, E8472 \\
\hline $\begin{array}{l}\text { Glycyl-2-naphthylamide hydrolase pro- } \\
\text { duction }^{a}\end{array}$ & $9 / 13$ & + & D7039, D7529, E3438, E6209 \\
\hline $\begin{array}{l}\text { L-Arginyl-2-naphthylamide hydrolase pro- } \\
\text { duction }^{a}\end{array}$ & $9 / 13$ & + & D7039, D7529, E6209, E6826 \\
\hline $\begin{array}{l}\text { L-Leucyl-glycyl-2-naphthylamide hydro- } \\
\text { lase production }{ }^{a}\end{array}$ & $9 / 13$ & + & D7039, D7529, E6826, E8472 \\
\hline $\begin{array}{l}N \text {-Carbobenzoxy-L-arginyl-4-methoxyl- } \\
\text { 2-naphthylamide hydrolase production }{ }^{a}\end{array}$ & $9 / 13$ & - & CL404/79, D7039, E3438, E7288 \\
\hline $\begin{array}{l}\text { Glycyl-L-prolyl-2-naphthylamide hydro- } \\
\text { lase production }{ }^{a}\end{array}$ & $8 / 13$ & + & D7039, D7529, E6209, E6826, E8472 \\
\hline $\begin{array}{l}\text { L-Glutaminyl-2-naphtylamide hydrolase } \\
\text { production }^{a}\end{array}$ & $8 / 13$ & + & D7039, D7529, E3438, E6209, E6826 \\
\hline $\begin{array}{l}\alpha-L \text {-Glutamyl-2-naphthylamide hydrolase } \\
\text { production }^{a}\end{array}$ & $8 / 13$ & + & D7529, E3438, E6209, E6826, E8472 \\
\hline $\begin{array}{l}N \text {-Carbobenzoxy-glycyl-glycyl- } \mathrm{L} \text {-arginyl- } \\
\text { 2-naphthylamide hydrolase production }\end{array}$ & $8 / 13$ & + & D7039, D7529, E3438, E6209, E8472 \\
\hline Esterase-lipase $(C-8)$ production ${ }^{a . b}$ & $7 / 13$ & - & $\begin{array}{l}\text { D3250, E3438, E6209, E6826, E7288, } \\
\text { E8472 }\end{array}$ \\
\hline $\begin{array}{l}\text { L-Glycyl-glycyl-2-naphthylamide hydro- } \\
\text { lase production }{ }^{\alpha}\end{array}$ & $7 / 13$ & - & $\begin{array}{l}\text { CL48/80, D7039, D7529, E6209, E6826, } \\
\text { E7288 }\end{array}$ \\
\hline Exo-1, 4- $\beta-\mathrm{D}-\mathrm{xylosidase}$ production ${ }^{a}$ & $6 / 13$ & - & $\begin{array}{l}\text { CL404/79, A14/65, D3221, D3250, E6209, } \\
\text { E8472 }\end{array}$ \\
\hline$\alpha-\mathrm{L}-$ Arabinofuranosidase production ${ }^{a}$ & $6 / 13$ & + & $\begin{array}{l}\text { CL48/80, D3221, D7529, E6209, E7288, } \\
\text { E8472 }\end{array}$ \\
\hline $\begin{array}{l}\text { L-Methionyl-2-naphthylamide hydrolase } \\
\text { production }^{a}\end{array}$ & $6 / 13$ & - & $\begin{array}{l}\text { CL404/79, CL48/80, A14/65, D3221, } \\
\text { D3250, D7211 }\end{array}$ \\
\hline $\begin{array}{l}\text { L-Seryl-tyrosyl-2-naphthylamide hydro- } \\
\text { lase production }{ }^{a}\end{array}$ & $6 / 13$ & - & $\begin{array}{l}\text { CL404/79, CL48/80, A14/65, D3250, } \\
\text { D7211, E3438 }\end{array}$ \\
\hline $\begin{array}{l}\text { L-Ornithyl-2-naphthylamide hydrolase } \\
\text { production }{ }^{a}\end{array}$ & $6 / 13$ & - & $\begin{array}{l}\text { CL404/79, CL48/80, A14/65, D3221, } \\
\text { D3250, D7211 }\end{array}$ \\
\hline $\begin{array}{l}\text { L-Seryl-2-naphthylamide hydrolase pro- } \\
\text { duction }^{a}\end{array}$ & $6 / 13$ & - & $\begin{array}{l}\text { CL404/79, A14/65, D3221, D3250, D7211, } \\
\text { E6209 }\end{array}$ \\
\hline $\begin{array}{l}\text { L-Tryptophyl-2-naphthylamide hydrolase } \\
\text { production }^{a}\end{array}$ & $6 / 13$ & - & $\begin{array}{l}\text { CL404/79, CL48/80, A14/65, D3221, } \\
\text { D3250, D7211 }\end{array}$ \\
\hline Arylsulfatase production ${ }^{a}$ & $4 / 13$ & - & CL48/80, A14/65, E3438, E6826 \\
\hline $\begin{array}{l}\gamma \text {-L-Glutamyl-2-naphthylamide hydrolase } \\
\text { production }^{a}\end{array}$ & $4 / 13$ & - & CL404/79, A14/65, D3250, D7211 \\
\hline $\begin{array}{l}S \text {-Benzyl-L-cysteyl-2-naphthylamide hy- } \\
\text { drolase production }{ }^{a}\end{array}$ & $4 / 13$ & - & CL404/79, A14/65, D3250, D7211 \\
\hline $\begin{array}{l}\text { L-Threonyl-2-naphthylamide hydrolase } \\
\text { production }^{a}\end{array}$ & $4 / 13$ & - & CL404/79, A14/65, D3250, D7211 \\
\hline
\end{tabular}


TABLE 4-Continued

\begin{tabular}{|c|c|c|c|}
\hline Strain differences & $\begin{array}{l}\text { No. of } \\
\text { strains } \\
\text { positive }\end{array}$ & $\begin{array}{c}\text { Result } \\
\text { of type } \\
\text { strain } \\
(\mathrm{E} 7288)\end{array}$ & $\begin{array}{c}\text { Reference no. of strains that gave the less } \\
\text { common result }\end{array}$ \\
\hline $\begin{array}{l}\text { Acid from arabinose (ammonium salt sug- } \\
\text { ar medium) }\end{array}$ & $3 / 13$ & - & D3250, E6209, E8472 \\
\hline $\begin{array}{l}\text { L-Leucyl-2-naphthylamide hydrolase pro- } \\
\text { duction }{ }^{a, b}\end{array}$ & $3 / 13$ & - & CL404/79, CL48/80, A14/65 \\
\hline$\alpha$-L-Fucosidase production ${ }^{a, b}$ & $3 / 13$ & - & CL48/80, A14/65, D3250 \\
\hline $\begin{array}{l}\text { Glycyl-L-phenylalanyl-2-naphthylamide } \\
\text { hydrolase production }{ }^{a}\end{array}$ & $2 / 13$ & - & CL404/79, A14/65 \\
\hline $\begin{array}{l}\text { Acid from rhamnose (ammonium salt sug- } \\
\text { ar medium) }\end{array}$ & $1 / 13$ & - & A14/65 \\
\hline $\mathrm{KCN}$ tolerance & $1 / 13$ & - & E8472 \\
\hline$\beta$-D-Galactosidase production ${ }^{a, b}$ & $1 / 13$ & - & D3221 \\
\hline$\beta-\mathrm{D}-$ Glucosidase production ${ }^{a . b}$ & $1 / 13$ & - & D3221 \\
\hline Phosphatase production ${ }^{a}$ & $1 / 13$ & - & E3438 \\
\hline $\begin{array}{l}\text { L-Pyroglutamyl-2-naphthylamide hydro- } \\
\text { lase production }{ }^{a}\end{array}$ & $1 / 13$ & - & D3250 \\
\hline
\end{tabular}

${ }^{a}$ Tested using various API ZYM galleries.

${ }^{b}$ Enzyme test included in the standard API ZYM gallery.

tion of Flavobacterium as emended by Holmes and Owen (7), although members of the species were not markedly yellow pigmented and they were not as actively proteolytic as most species in the genus (i.e., F. balustinum, " $F$. breve," $F$. meningosepticum, and $F$. odoratum). Furthermore, the $\mathrm{G}+\mathrm{C}$ values of 40 to $42 \mathrm{~mol} \%$ obtained for $F$. spiritivorum were higher than the values of other recognized species of Flavobacterium (see Table 7). These results indicate that the G + C range of Flavobacterium (7) should be widened to 31 to $42 \mathrm{~mol} \%$. Characteristics for the practical identification of the new species are recorded in Table 7. $P$. paucimobilis is included in Table 7 because it has biochemical properties similar to those of $F$. multivorum and $F$. spiritivorum. Table 7 shows that the new species was most similiar to $F$. multivorum. There were consistent differences between $F$. multivorum and $F$. spiritivorum in two conventional tests (production of acid, in ammonium salt medium, from ethanol and from mannitol) and in one API ZYM test (production of L-phenylalanyl-2naphthylamide hydrolase). There was a small but significant ( $>2 \times$ standard deviation) difference in the mean $\mathrm{G}+\mathrm{C}$ contents of the two species $(39.6 \mathrm{~mol} \% \mathrm{G}+\mathrm{C}$ for $F$. multivorum compared with $41.4 \% \mathrm{G}+\mathrm{C}$ for $F$. spiritivorum).

Most strains of $F$. spiritivorum were isolated from clinical specimens, of which blood and urine were the most common sources. Their clinical significance cannot be assessed at present, but their resistance to a wide range of antimicrobial agents indicates that any infections in humans due to such bacteria could prove difficult to treat. Resistance to antimicrobial agents is a characteristic that $F$. spiritivorum shares with most other Flavobacterium species $(1,10-14,27)$.

Description of the type strain. The characteristics of the type strain, E7288 (= NCTC 11386), also listed in Tables 2 through 6 , are as follows:

Gram-negative, nonsporeforming rods, 1.0 $\mu \mathrm{m}$ in length, of regular shape with rounded ends. Nonmotile in hanging-drop preparations after overnight growth in nutrient broth incubated at either $37^{\circ} \mathrm{C}$ or room temperature.

Circular, low convex, smooth, and opaque colonies developing on nutrient agar after 2 days; colonies nonhemolytic on $5 \%$ (vol/vol) horse blood agar; on nutrient agar, a yellow, nonfluorescent pigment is produced. There is no production of brown pigment on tyrosine agar.

Aerobic.

Growth at $37^{\circ} \mathrm{C}$ but not at 5 or $42^{\circ} \mathrm{C}$. Optimal temperature: about $30^{\circ} \mathrm{C}$.

Production of catalase, cytochrome oxidase, and deoxyribonuclease.

Production of urease.

No toleration of $\mathrm{KCN}$ at a concentration of $0.0075 \%(\mathrm{wt} / \mathrm{vol})$. Hydrolysis of Tween 20 and Tween 80 .

No production of opalescence on lecithovitellin agar.

No reduction of nitrate to nitrite; no reduction of nitrite.

No production of indole or hydrogen sulfide.

Growth on $\beta$-hydroxybutyrate (without production of lipid inclusion granules) and on MacConkey agar, but not on cetrimide agar.

No digestion of casein.

Hydrolysis of esculin, gelatin, and tributyrin, but not starch or tyrosine.

No utilization of citrate and malonate. 


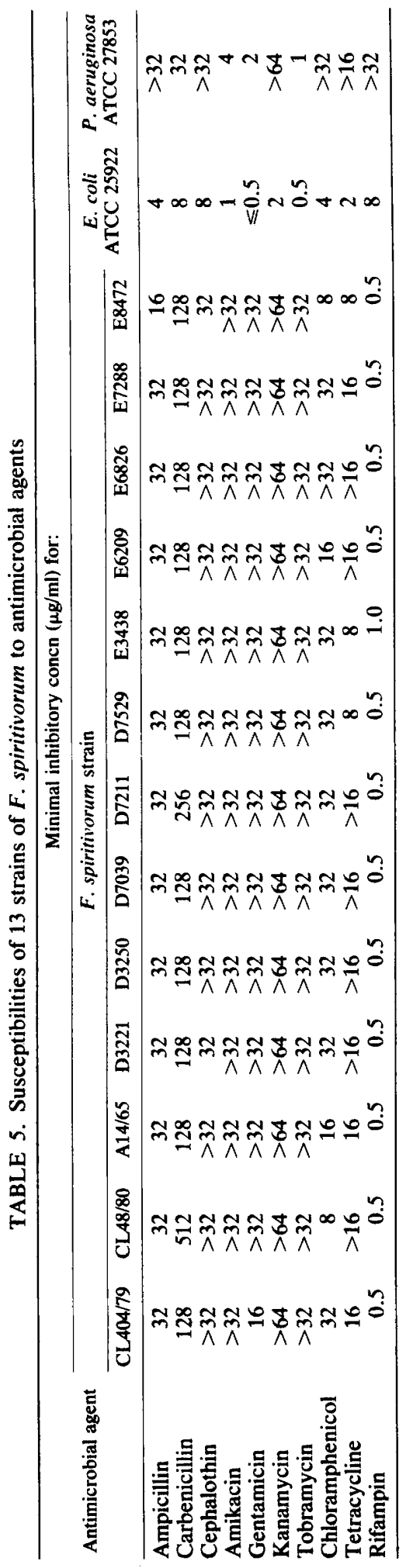

TABLE 6. DNA base compositions of six strains of $F$. spiritivorum

\begin{tabular}{lccc}
\hline \multicolumn{1}{c}{ Strain } & Buffer & $T_{m} \pm \mathrm{SD}^{b}\left({ }^{\circ} \mathrm{C}\right)$ & $\begin{array}{c}\mathrm{G}+\mathrm{C} \text { content } \\
(\mathrm{mol} \%)\end{array}$ \\
\hline E8472 & $0.33 \times$ SSC & $78.2 \pm 0.20$ & $40.8^{c}$ \\
E7288 & $0.33 \times$ SSC & $78.3 \pm 0.20$ & 41.0 \\
CL48/80 & $0.33 \times$ SSC & $78.4 \pm 0.00$ & 41.3 \\
E6209 & $0.33 \times$ SSC & $78.4 \pm 0.10$ & 41.3 \\
A14/65 & SSC & $86.5 \pm 0.05$ & $41.8^{d}$ \\
CL404/79 & $0.33 \times$ SSC & $78.7 \pm 0.30$ & 41.9
\end{tabular}

Mean \pm SD

$41.4 \pm 0.4$

${ }^{a}$ Compositions of the buffers used: $0.33 \times \mathrm{SSC}, 0.05$ $\mathrm{M} \mathrm{NaCl}$ and $0.005 \mathrm{M}$ trisodium citrate; SSC, $0.15 \mathrm{M}$ $\mathrm{NaCl}$ and $0.015 \mathrm{M}$ trisodium citrate.

${ }^{b}$ The thermal denaturation temperature $\left(T_{m}\right)$ is the mean of two or three determinations and the standard deviation (SD).

c The equation used to calculate $\mathrm{G}+\mathrm{C}$ content was: $\mathrm{mol} \% \mathrm{G}+\mathrm{C}=52.0+\left[2.24\left(T_{m}-83.2\right)\right]$.

${ }^{d}$ This value was published previously (9).

No oxidation of gluconate.

No production of arginine desimidase, arginine dihydrolase, lysine decarboxylase, or ornithine decarboxylase.

No produciton of 3-ketolactose.

No reduction of selenite and no deamination of phenylalanine.

Production of phosphatase and $\beta$-D-galactosidase (when tested, respectively, by method 1 of Cowan [2] and the method given by Holmes et al. [6]).

Production of acid in ammonium salt medium under aerobic conditions from glucose, cellobiose, glycerol, ethanol, fructose, lactose, maltose, mannitol, raffinose, salicin, sucrose, trehalose, and xylose.

Production of acid from $10 \%$ (wt/vol) glucose and $10 \%(\mathrm{wt} / \mathrm{vol})$ lactose.

No production of acid in ammonium salt medium under aerobic conditions from adonitol, arabinose, dulcitol, inositol, rhamnose, or sorbitol.

Production of acid, but not gas, from glucose in peptone-water medium; production of acid in only the open tube of Hugh and Leifson oxidation-fermentation glucose medium.

Production of the following enzymes (using various API ZYM galleries): alkaline phosphatase, $N$-benzoyl-DL-arginyl-2-naphthylamide hydrolase, acid phosphatase, phosphoamidase, $\alpha$ D-glucosidase, $\quad N$-acetyl- $\beta$-D-glucosaminidase, $\alpha$-L-arabinofuranosidase, $\beta$-D-cellobiosidase, $L$ lysyl-2-naphthylamide hydrolase, L-histidyl-2naphthylamide hydrolase, glycyl-2-naphthylamide hydrolase, $\alpha$-L-aspartyl-2-naphthylamide hydrolase, L-arginyl-2-naphthylamide hydrolase, L-alanyl-2-naphthylamide hydrolase, glycyl-L-prolyl-2-naphthylamide hydrolase, L-leucyl-glycyl-2- 
TABLE 7. Characteristics for the practical identification and differentiation of $F$. spiritivorum from other $F$ lavobacterium taxa and from $P$.

\begin{tabular}{|c|c|c|c|c|c|c|c|c|}
\hline Test & $\begin{array}{c}\text { F. spiritivorum } \\
\text { (13 strains) }\end{array}$ & $\begin{array}{c}F . \text { balustinum } \\
\text { (1 strain) }\end{array}$ & $\begin{array}{l}\text { "F. breve"b } \\
\text { (7 strains) }\end{array}$ & $\begin{array}{c}\text { F. meningosepticum } \\
\text { (49 strains) }\end{array}$ & $\begin{array}{l}\text { F. multivorum } \\
\text { (28 strains) }\end{array}$ & $\begin{array}{c}\text { F. odoratum } \\
\text { (28 strains) }\end{array}$ & $\begin{array}{c}\text { Flavobacterium } \\
\text { sp. group IIb } \\
\text { (55 strains) }\end{array}$ & $\begin{array}{c}\text { P. paucimobilise } \\
\text { (29 strains) }\end{array}$ \\
\hline $\begin{array}{l}\text { Acid from ASS glucose } \\
\text { Acid from ASS arabinose } \\
\text { Acid from ASS cellobiose } \\
\text { Acid from ASS ethanol } \\
\text { Acid from ASS glycerol } \\
\text { Acid from ASS lactose } \\
\text { Acid from ASS maltose } \\
\text { Acid from ASS mannitol } \\
\text { Acid from ASS raffinose } \\
\text { Acid from ASS salicin } \\
\text { Acid from ASS sucrose } \\
\text { Acid from ASS trehalose } \\
\text { Acid from ASS xylose } \\
\text { Casein digestion } \\
\text { Esculin hydrolysis } \\
\text { Gelatinase production } \\
\text { (plate method) } \\
\text { Growth on MacConkey agar } \\
\text { Indole production } \\
\text { (Ehrlich's reagent) } \\
\text { Motility at room temperature } \\
\text { Nitrite reduction } \\
\text { Poly- } \beta \text {-hydroxybutyrate inclusion } \\
\text { granules } \\
\text { Starch hydrolysis } \\
\text { Urease production } \\
\beta \text {-D-Galactosidase production } \\
\text { Mol\% G+C } \pm \text { standard deviation }\end{array}$ & $\begin{array}{c}+ \\
3 / 13^{8} \\
+ \\
+ \\
+ \\
+ \\
+ \\
+ \\
+ \\
+ \\
+ \\
+ \\
+ \\
- \\
+ \\
+\end{array}$ & $\begin{array}{l}+ \\
- \\
- \\
+ \\
- \\
- \\
- \\
- \\
- \\
- \\
- \\
- \\
- \\
+ \\
+ \\
+ \\
+ \\
+ \\
+ \\
+ \\
+\end{array}$ & $\begin{array}{c}6 / 7 \\
- \\
- \\
- \\
- \\
- \\
6 / 7 \\
- \\
- \\
- \\
- \\
- \\
- \\
+ \\
- \\
+ \\
+ \\
+ \\
- \\
- \\
- \\
- \\
- \\
- \\
\pm 0.6(10)\end{array}$ & $\begin{array}{c}42 / 49 \\
1 / 49 \\
4 / 49 \\
28 / 49 \\
38 / 49 \\
27 / 49 \\
46 / 49 \\
31 / 49 \\
- \\
- \\
- \\
42 / 49 \\
3 / 49 \\
+ \\
47 / 49 \\
+ \\
+ \\
24 / 49 \\
- \\
18 / 49 \\
- \\
- \\
16 / 49 \\
48 / 49 \\
0.5(8)\end{array}$ & $\begin{array}{c}+ \\
+ \\
+ \\
- \\
27 / 28 \\
+ \\
+ \\
- \\
+ \\
+ \\
+ \\
+ \\
+ \\
- \\
+ \\
4 / 28 \\
+ \\
- \\
- \\
- \\
- \\
- \\
27 / 28 \\
+ \\
39.6 \pm 0.5(11)\end{array}$ & $\begin{array}{c}- \\
- \\
- \\
- \\
- \\
- \\
- \\
- \\
- \\
- \\
- \\
- \\
+ \\
- \\
+ \\
+ \\
- \\
- \\
+ \\
- \\
- \\
+ \\
- \\
31.4-36.1(10)\end{array}$ & $\begin{array}{c}+ \\
13 / 55 \\
3 / 55 \\
9 / 55 \\
35 / 55 \\
- \\
+ \\
3 / 55 \\
- \\
1 / 55 \\
12 / 55 \\
48 / 55 \\
9 / 55 \\
+ \\
52 / 55 \\
+ \\
\\
51 / 55 \\
53 / 55 \\
- \\
14 / 55 \\
-\end{array}$ & $\begin{array}{c}+ \\
+ \\
+ \\
26 / 29 \\
6 / 29 \\
+ \\
+ \\
- \\
28 / 29 \\
26 / 29 \\
+ \\
+ \\
+ \\
- \\
+ \\
3 / 29\end{array}$ \\
\hline
\end{tabular}

${ }^{a}$ Key: + , All strains tested positive; - , all strains tested negative. The phenotypic results for $F$. spiritivorum were from this study, and the phenotypic results for the other taxa were derived from previous work in the National Collection of Type Cultures: $F$. balustinum (B. Holmes and R. J. Owen, unpublished data), "F. breve"' (12), F. meningosepticum (Holmes and Owen, unpublished data), F. multivorum (10), F. odoratum (13), Flavobacterium sp. group Ilb (Holmes and Owen, unpublished data), and $P$. paucimobilis (9). The G+C values for $F$. spiritivorum were obtained in this study, and the results on the other taxa were derived as follows: $F$. balustinum $(22)$, " $F$. breve" (22), $F$. meningosepticum $(23,24), F$. multivorum $(10), F$. odoratum $(21)$, Flavobacterium sp. group IIb (Holmes and Owen, unpublished data), and $P$. paucimobilis (9). The numbers of strains tested in each species for mol\% $\mathbf{G}+\mathbf{C}$ are given in parentheses.

$b$ The name " $F$, breve" is in publication).

c Formerly known as group IIk, biotype $2(10,26)$.

${ }^{d}$ Formerly known as group $\mathbf{M - 4 f}(11,26)$.

e Formerly known as group IIk, biotype $1(9,26)$.

$f$ ASS, Ammonium salt sugar medium.

${ }^{8}$ Number of strains showing characteristic/number of strains tested. 
naphthylamide hydrolase, L-glutaminyl-2-naphthylamide hydrolase, $\alpha$-L-glutamyl-2-naphthylamide hydrolase, $N$-carbobenzoxy-glycyl-L-arginyl-2naphthylamide hydrolase.

No production of the following enzymes (using various API ZYM galleries): esterase (C-4), esterase-lipase (C-8), lipase (C-14), L-leucyl-2naphthylamide hydrolase, L-valyl-2-naphthylamide hydrolase, L-cystyl-2-naphthylamide hydrolase, $N$-glutaryl-L-phenylalanyl-2-naphthylamide hydrolase, $\alpha$-D-galactosidase, $\beta$-D-galactosidase, $\beta$ $D$-glucuronidase, $\beta$-D-glucosidase, $\alpha$-D-mannosidase, $\alpha$-L-fucosidase, exo-1,4- $\beta$-D-xylosidase, phosphatase, $\alpha$-D-xylosidase, $\beta$-D-fucosidase, $\beta$-Lfucosidase, $\quad N$-acetyl- $\alpha$-D-glucosaminidase, lactosidase, arylsulfatase, L-tyrosyl-2-naphthylamide hydrolase, L-pyroglutamyl-2-naphthylamide hydrolase, L-phenylalanyl-2-naphthylamide hydrolase, L-hydroxyprolyl-2-naphthylamide hydrolase, $\gamma$-L-glutamyl-2-naphthylamide hydrolase, $N$-benzoyl-1-leucyl-2-naphthylamide hydrolase, $S$-benzyl-Lcysteyl-2-naphthylamide hydrolase, L-methionyl-2naphthylamide hydrolase, L-glycyl-glycyl-2naphthylamide hydrolase, glycyl-L-phe-nylal-alanyl-2-naphthylamide hydrolase, L-seryl-tyrosyl2-naphthylamide hydrolase, $N$-carbobenzoxy-Larginyl-4-methoxyl-2-naphthylamide hydrolase, L-isoleucyl-2-naphthylamide hydrolase, L-ornithyl-2-naphthylamide hydrolase, i-prolyl-2-naphthylamide hydrolase, L-seryl-2-naphthylamide hydrolase, L-threonyl-2-naphthylamide hydrolase, L-tryptophyl-2-naphthylamide hydrolase.

Resistant to ampicillin, carbenicillin, cephalothin, amikacin, gentamicin, kanamycin, tobramycin, chloramphenicol, and tetracýcline. Susceptible to rifampin.

$\mathrm{G}+\mathrm{C}$ content of DNA: $41.0 \mathrm{~mol} \%$ (thermal denaturation temperature estimation).

Source: isolated from an intrauterine specimen.

Two additional strains of $F$. spiritivorum have been deposited in the National Collection of Type Cultures: A14/65 as NCTC 11387 and CL48/80 as NCTC 11388.

\section{ACKNOWLEDGMENTS}

We are most grateful to Carolyn Baker for assistance with the antimicrobial susceptibility determinations and to API System for the supply of ZYM galleries. The members of the staff of the NCTC Computer Identification Laboratory are thanked for their help, in particular M. S. Ahmed for technical assistance.

\section{REPRINT REQUESTS}

Address reprint requests to: Dr. D. G. Hollis, Building 5, Room 210, Centers for Disease Control, Atlanta, GA 30333.

\section{LITERATURE CITED}

1. Altmann, G., and B. Bogokovsky. 1971. In-vitro sensitivity of Flavobacterium meningosepticum to antimicrobial agents. J. Med. Microbiol. 4:296-299.

2. Cowan, S. T. 1974. Cowan and Steel's manual for the identification of medical bacteria, 2nd ed. Cambridge University Press, London.

3. Dees, S. B., C. W. Moss, R. E. Weaver, and D. Hollis. 1979. Cetlular fatty acid composition of Pseudomonas paucimobilis and groups IIk-2, Ve-1, and Ve-2. J. Clin. Microbiol. 10:206-209.

4. Hayes, P. R. 1977. A taxonomic study of flavobacteria and related gram negative yellow pigmented rods. J. Appl. Bacteriol. 43:345-367.

5. Hill, L. R. 1968 . The determination of deoxyribonucleic acid base compositions and its application to bacterial taxonomy, p. 177-186. In B. M. Gibbs and D. A. Shapton (ed.), Identification methods for microbiologists, part B. Academic Press, London.

6. Holmes, B., S. P. Lapage, and H. Malnick. 1975. Strains of Pseudomonas putrefaciens from clinical material. J. Clin. Pathol. 28:149-155.

7. Holmes, B., and R. J. Owen. 1979. Proposal that Flavobacterium breve be substituted as the type species of the genus in place of Flavobacterium aquatile and emended description of the genus Flavobacterium: status of the named species of Flavobacterium. Request for an opinion. Int. J. Syst. Bacteriol. 29:416-426.

8. Holmes, B., and R. J. Owen. 1981. Emendation of the genus Flavobacterium and the status of the genus. Developments after the 8th edition of Bergey's Manual, p. 1726. In $\mathrm{H}$. Reichenbach and $\mathrm{O}$. B. Weeks (ed.), The Flavobacterium-Cytophaga Group (Proceedings of the International Symposium on Yellow-Pigmented GramNegative Bacteria of the Flavobacterium-Cytophaga Group, Braunschweig, 8 to 11 July 1980). Verlag Chemie, Weinheim.

9. Holmes, B., R. J. Owen, A. Evans, H. Malnick, and W. R. Willcox. 1977. Pseudomonas paucimobilis, a new species isolated from human clinical specimens, the hospital environment, and other sources. Int. J. Syst. Bacteriol. 27:133-146.

10. Holmes, B., R. J. Owen, and R. E. Weaver. 1981. Flavobacterium multivorum, a new species isolated from human clinical specimens and previously known as group IIK, biotype 2. Int. J. Syst. Bacteriol. 31:21-34.

11. Holmes, B., J. J. S. Snell, and S. P. Lapage. 1977. Revised description, from clinical isolates, of Flavobacterium odoratum Stutzer and Kwaschnina 1929 and designation of the neotype strain. Int. J. Syst. Bacteriol. 27:330-336.

12. Holmes, B., J. J. S. Snell, and S. P. Lapage. 1978. Revised description, from clinical strains, of Flavobacterium breve (Lustig) Bergey et al. 1923 and proposal of the neotype strain. Int. J. Syst. Bacteriol. 28:201-208.

13. Holmes, B., J. J. S. Snell, and S. P. Lapage. 1979. Flavobacterium odoratum: a species resistant to a wide range of antimicrobial agents. J. Clin. Pathol. 32:73-77.

14. King, E. O. 1959. Studies on a group of previously unclassified bacteria associated with meningitis in infants. Am. J. Clin. Pathol. 31:241-247.

15. King, E. O., M. K. Ward, and D. E. Raney. 1954. Two simple media for the demonstration of pyocyanin and fluorescein. J. Lab. Clin. Med. 44:301-307.

16. Lapage, S. P., and W. R. Willcox. 1974. A simple method for analysing binary data. J. Gen. Microbiol. 85:376-380.

17. Marmur, J. 1961. A procedure for the isolation of deoxyribonucleic acid from micro-organisms, J. Mol. Biol. 3:208-218.

18. Marmur, J., and P. Doty. 1962. Determination of the base composition of deoxyribonucleic acid from its thermal denaturation temperature. J. Mol. Biol. 5:109-118.

19. National Committee for Clinical Laboratory Standards. 1980. Standard methods for dilution antimicrobial susceptibility tests for bacteria which grow aerobically (proposed standard PSM-7). National Committee for Clinical Laboratory Standards, Villanova, Pa.

20. Owen, R. J., L. R. Hill, and S. P. Lapage. 1969. Determination of DNA base compositions from melting profiles in 
dilute buffers. Biopolymers 7:503-516.

21. Owen, R. J., and B. Holmes. 1978. Heterogeneity in the characteristics of deoxyribonucleic acid from Flavobacterium odoratum. FEMS Microbiol. Lett. 4:41-46.

22. Owen, R. J., and B. Holmes. 1980. Differentiation between strains of Flavobacterium breve and allied bacteria by comparisons of deoxyribonucleic acids. Curr. Microbiol. 4:7-11.

23. Owen, R. J., and S. P. Lapage. 1974. A comparison of strains of King's group IIb of Flavobacterium with Flavobacterium meningosepticum. Antonie van Leeuwenhoek J. Microbiol. Serol. 40:255-264.

24. Owen, R. J., and J. J. S. Snell. 1976. Deoxyribonucleic acid reassociation in the classification of flavobacteria. $J$. Gen. Microbiol. 93:89-102.

25. Skerman, V. B. D., V. McGowan, and P. H. A. Sneath (ed.). 1980. Approved lists of bacterial names. Int. J. Syst. Bacteriol. 30:225-420.

26. Tatum, H. W., W. H. Ewing, and R. E. Weaver. 1974. Miscellaneous gram-negative bacteria, p. 270-294. In E. H. Lennette, E. H. Spaulding, and J. P. Truant (ed.), Manual of clinical microbiology, 2nd ed. American Society for Microbiology, Washington, D.C.

27. Von Graevenitz, A., and M. Grehn. 1977. Susceptibility studies on Flavobacterium II-b. FEMS Microbiol. Lett. 2:289-292. 